\title{
The Impact of Government Debt on the Economic Growth of Ghana: A Time Series Analysis from 1990-2015
}

\author{
${ }^{1}$ Lucy Anning, ${ }^{2}$ Collins Frimpong Ofori , ${ }^{3}$ Ernest Kwame Affum \\ 1,3School of Business Administration, Zhongnan University of Economics and Law, Wuhan, \\ China \\ ${ }^{2}$ School of Accounting and Finance, Zhongnan University of Economics and Law, Wuhan, \\ China
}

\begin{abstract}
In this study we investigate the impact of government debt on the economic growth of Ghana adopting the methodology of the simple Ordinary Least Squares with data spanning from 1990 to 2015. Ghana has unfortunately found itself in the tragic situation of high external government debt which has led to high dependency on aid and other loans to support its development. These aids and loans have seen the debt of Ghana rise steadily over the years. As a result of the Heavily-Indebted Poor Countries (HIPC) which was presented by the IMF and World Bank in 1999, Ghana was judged to be a HIPC with unsustainable debt enabling the country to benefit from debt relief. We investigate the impact of government debt (both external and domestic) by testing three related models at the domestic and external levels including the general growth of the Ghanaian economy. In constructing our dataset, we build on the study of many scholars including a substantial amount of new materials from both primary and secondary data sources being Ministry of Finance (MOF) or Treasury Latest actual data: Government Finance Statistics Manual (GFSM), Ghana and World Bank. The research findings revealed that there is a negative relationship between debt (domestic and external) and growth in the economy of Ghana and recommend among others that government debt borrowing should be discouraged while increasing the revenue base through tax reform programs is encouraged.
\end{abstract}

Keywords: Domestic debt, External debt, Economic growth

\section{INTRODUCTION}

Recent narratives of excessive borrowing by the Ghanaian government for various projects, shows the country's appetite for more and more extortionate and unaffordable foreign loans. These actions have brought into sharp focus the scale of the crisis in Ghana's financial and economic wellbeing (Nyarko, 2014).

External debt can be described as the situation where governments face budget deficit due to the high expenditure and fewer revenues. The government of an economy can get revenue by increasing taxes, printing money, domestic or external borrowing and also using the previous budget surplus. When the government decides to borrow instead of introducing additional tax measures, to finance the budget deficit, it creates a liability on itself known as public (Sachs et al., 1985).

Ghana, has unfortunately found itself in the tragic situation of high external government debt which has led to high dependency on aid and other loans to support its development. These aids and loans have seen the debt of Ghana rise steadily over the years. As a result of the Heavily-Indebted Poor Countries (HIPC) initiative introduced by the IMF and World Bank in 1999, Ghana was judged to be a HIPC with unsustainable debt enabling the country to benefit from debt relief. Subsequently, Ghana 
benefitting from the Multilateral Debt Relief Initiative (MDRI) allowed it to attain total debt relieve from debts owed to monetary agents such as IMF, the International Development Association (IDA) of the World, and the African Development Bank (AfDB). Prior to these reliefs, the Ghanaian economy saw a sharp decline in its debt to a rather sustainable level. This debt relief allowed Ghana to step up its borrowing mostly to finance infrastructure projects which eventually saw the debt level rise again steadily (Barfour Osei 1995).

In the light of the above, this study on Ghana's government debt and its impact on the economic growth which is turning suicidal is an effort in the right direction. Thus the novelty value of this study cannot be overemphasized. The purpose of this study is to discover the impact of Ghana's external and internal government indebtedness for sustained economic growth. The focus of the analyses is on the debt of Ghana from 1990-2015, a period during which Ghana pursued an economic recovery program (ERP), adopted structural adjustment policies, HIPC and heightened increase in borrowings causing twin deficits. The study is intended to address estimation of the impact of the government debt on economic growth.

\subsection{Problem Statement}

Depending on both external loans and domestic borrowing for its developmental sustenance saw Ghana's debt rise over the years, reaching over $100 \%$ of GDP in 2000 . The record of some debt relieve aids in terms of loans among others have proven futile in a bid to relieve the economy of its suicidal debt distress.

This continuous rise in the domestic and external debt of Ghana has brought to the fore the need for the government of Ghana to formulate and implement practical debt management strategies to moderate the effects of the debt of the economy. The need to finance rising government expenditure has been identified to be responsible for the rapid increase in the stock of Ghana's domestic and external debt. Prior to the ongoing crisis it is of high essence that something needs to be done and this must be done with all urgency.

\subsection{Aim of the study}

In relation to this very difficult time of immense financial crisis in which Ghana finds itself, it would be an innovative and significant task to conduct a research work to provide insights and a more reliable guide for monitoring the challenges faced by Ghana as an economy in the realm of its suicidal debt crisis, creating an enabling environment to stimulate and ensure overall growth of the economy. Thus the aim of the study is to examine the inadequate government infrastructure and the ineffective management of domestic and external debt in Ghana. It is also set to analyze the structure and the dynamics of domestic, external and total debt, bringing out emerging vulnerabilities and future threats.

\section{LITERATURE REVIEW}

In the study of Fuenzalidaet al. (2008), they explored the causes and suddenness of international debt crisis and the existence of an excess supply of credit in the pre-crisis situation are theoretically investigated from a formal game-theoretic point of view. Here it was clearly envisaged over time in many developing countries that international debt crises come on very suddenly. From contrasting an excess supply of credit, a nation can within months or even weeks finds itself caught up in an acute foreign-exchange shortage situation. Emphasis is being made on the fact that International credit is an essential part of a nation's development process. The game theory model was used to give insight into the suddenness of the debt crises of the kind that India faced in 1991. Within the confines of this model, the borrowing countries can raise the interest rate and regain the confidence the lenders but in reality it will take time to regain this confidence.

Carmen et al. (2011) in their study of the debt crisis, from financial Crash to Debt crisis they found out that newly developed time series on public debt, along with data on external debts, allow a 
deeper analysis of the debt cycles underlying serial debt and banking crisis. They tested three related hypotheses at both world aggregate levels and on an individual country basis. With a data covering 70 countries in Africa, Asia, Europe, Latin America, North America and Oceania and a range of variables encompassing external and domestic debt, trade, Gross National Product (GNP), inflation, exchange rates and commodity prices, their analysis suggest more surprisingly that banking crisis (even those of a purely private origin) increase the likelihood of a sovereign default. They also found a direct effect (perhaps in part due to the recession that typically arises) as well as an indirect effect (perhaps due to the typical post banking crisis explosion in public debt.

Following a variant of Edwards et al. (1999) in their study of financial crisis saw a need to wake up to a new model(s) to be used in explaining the financial crisis of the moment. In their view it is difficult to assume that the generation one, two and three models of financial crisis are in the position to explain the current global financial crisis. The methodology employed in the explanation of the current financial crises is Fuzzy Cognitive Maps with regards to the non-conventional models. Their study resulted that the problem of financial crisis is extremely complex, where an innumerable quantity of financial, economic, social, ethical, technical and human behavior factors interfere and affect in the financial operations. In the case of the conception of a financial crisis, a model of advanced examination using distorted logic, the Fuzzy Cognitive Maps (FCM) is able to allow the addition of qualitative variables in the model, like financial regulation.

In another inspiring study, Trevino (2008) revealed that the economic and financial characteristics of the people, companies and public policies and habits of the US and other countries is not a significance of international crisis. They present some basic facts of the US economy such as saving rates, debt among other factors which help us understand this crisis and to be able to understand the size compared to other crisis in other countries or other crisis before the 1929 crisis. They concluded their findings on the fact that financial crisis is based less on a cause and more on the economic structures of the financial system.

Fuenzalida et al. 2008, in their research findings, explained that to investigate crisis, one can examine the schemes and strategies that may be employed to help manage this type of episodes. Nevertheless, periods of turmoil in developing capital markets could be anticipated through historical technical analysis; their study included the multifractal properties of three Latin American developing markets during the Mexican crisis of 1994: Argentina and two other countries being Brazil and Peru using exploring returns between 1989 and 2000. Employing the crisis-switching indicator with an empirical threshold, the analysis results revealed that unexpected variations in a version of the sequence of Holder advocates was usually followed by raging periods within a period of about sixty days.

Taking into account the well-known 'tequila effect', Cortez et al. 2008, investigated the impact that the unexpected financial crisis of Mexico in 1994 had on Argentina. They took into account the expected financial crisis of the USA and the consequent effect it will have on the Mexican economy. Defining transmission as a major surge in the correlation which can be either negative or positive between the economic and financial variables of two or more countries, induced by an external shock (Edwards and Susmel, 1999). The study employed the Bakeart et al. (2002) with a modified version of Lagunes and Watkins (2008) to justify for the confirmation of transmission and concluded that the inter-relational emphasis on the economy of the United States was embedded in their hypothesis which was affecting Argentina and Mexican countries significantly.

Using the simulation model and merging quantitative and qualitative research methods, Lukasz (2013), examined the significance of employing a cross-European stock markets survey that would ultimately make equity investment less stimulating during the episodes of global financial crises. The study findings remarked that the crisis affecting some equity markets were transmitted to other markets when investors, especially large institutional practitioners began to sell their equities traded in their host markets and other European bourses influencing a decline in the values of portfolios 
held by other market participants. Finally, the simulation again highlighted the negative influence of the financial crisis on the liquidity in the European stock markets.

With the aim of examining the global financial crisis ElioIannuzzi Massimiliano Berardi, (2010), used the complexity theory and viable system approach to examine the main causes of global financial crisis and perspectives to defining ways in which it can be managed in the future. The study debated the need for a somewhat revised International Financial System having the basic function of coordinating and guiding the different national and international institutions. Analysis of the trends in the debt levels and economic performance of the sub-Saharan countries and assessment of a couple of suggestions for the reduction of the external debt service obligations was investigated by Joshua Greene (1989).

The findings of this study revealed that several initiatives had been established within the past years in a bid to solve the debt crisis dilemma in sub-Saharan Africa. A couple of these initiatives included the Enhanced Structural Adjustment Facility (ESAF), Fund's Structural Adjustment Facility (SAF) and the World Bank's Special intense debt relief strategy to the extremely low-income countries. The study emphasized these proposals to support such countries in meeting their debt service obligations to multilateral organizations, measure for bilateral debt forgiveness and more general debt forgiveness measures aimed at eradicating bilateral and multilateral debt and providing all future assistance in the form of grants.

Running a regression on two panels Omotoye et al. (2006), investigated Africa's debt crisis and uncovered key explanatory variables with their degree of robustness ranging from very strong to moderate and somewhat significant such as terms of trade, inflation, non-petroleum revenue and privatization index. They concluded along with other factors that a history of political instability and the nonexistence of permanency in sound economic policies also ignited the debt crises in the economy of Nigeria.

Michael D. Bordo et al. (2010) also studied the effects of foreign currency debt on currency and debt crisis and its indirect effect on growth (short and long term output effects). Their use of the multivariate growth regressions among other methods in their analysis showed that hard currency debt is only but a partial explanation of the risks of financial crisis. In conclusion, they remarked that although some countries have on the recent started to minimize currency incompatibilities, uneven development, misguided and unregulated credit booms, sudden stops and contagion continue to pose dangers of the financial crisis.

Following the variance of previous studies on this subject matter, the current study intends to derive relevant thresholds including new and or (better) models for sustainable eternal debt and finally highlight quantifiable improvements that Ghana can employ to experience better governance infrastructure and effective management of external shocks other than relying on grants and aids amidst borrowing to pay its existing debts. Thus the novelty value of this study cannot be overemphasized.

\section{RESEARCH METHODOLOGY}

This chapter focuses on the methodology of the study by the formulation of models with particular emphasis on the Ordinary Least Square (OLS) to capture the impact of government debt on economic growth as discussed in earlier chapter.

\subsection{Considerations based on industry}

The research made an analysis on the economy of Ghana within the period of 1990-2015. The two main primary and secondary sources of information used in this study are the Ministry of Finance or Treasury Latest actual data: Government Finance Statistics Manual (GFSM) and World Bank data. The Domestic government debt, External government debt and Domestic and National savings data 
were obtained from the Ministry of Finance or Treasury Latest actual data: Government Finance Statistics Manual (GFSM), Ghana while the Private consumption expenditures, Investment expenditures, Inflation, Import, Government consumption expenditures were also obtained from the World Bank. The simple Ordinary Least Square (OLS) method of regression was used while majority of the independent variables were normalized using percentage GDP.

\subsection{Model Specification}

In line with the theoretical underpinning, the functional form of the models used in this study in relation to public debt and economic growth is specified as follows;

\section{Model 1:}

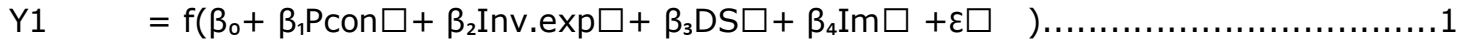

Where;

Pcon = Private Consumption Expenditure

Inv.exp = Investment expenditure

DS = Domestic Savings

Im $=$ Import

\section{Model 2:}

Y2 $=f\left(\beta_{0}+\beta_{1}\right.$ Gcon $\square+\beta_{2}$ Inv.exp $\square+\beta_{3}$ NS $\square+\beta_{4}$ Inf $\left.+\varepsilon \square\right) \ldots \ldots \ldots \ldots \ldots \ldots \ldots . . \ldots \ldots$

Where;

Y2 = External Debt

Gcon = Government Consumption expenditures

Inv.exp = Investment expenditure

NS = National Savings

Inf = Inflation

\section{Model 3:}

Gro $=f\left(\beta_{0}+\beta_{1} D D+\beta_{2} E D\right)$

Where;

Gro = Growth

DD = Domestic Debt

ED = External Debt

The choice to normalize the relevant variables in the study by percentage GDP is due to special reasons intended to eliminate some econometric problems such as the multi-collinearity among the variables.

\section{DATA ANALYSIS AND INTERPRETATION}

As was indicated from the above, the Ordinary Least Squares was adopted for the estimation of models. Ordinary least squares (OLS) method of regression was used to evaluate the slope of the coefficients of the autoregressive model. The use of OLS relies on the stochastic process being stationary. In the case where the stochastic process is not stationary, the use of OLS can result in invalid estimates. These estimates are called 'spurious regression' results thus high adjusted R2 values and high t-ratios yielding results with no economic meaning. Estimation is done by using $\mathrm{E}$ Views (Econometric Views), and results are significant. A total of 26 observations are included from 1990 to 2015 and three models are estimated to capture the impact of government debt on general economic growth of Ghana.

\section{Estimation of Model 1:}

The estimation of model one being the Domestic Debt is expressed in the functional form below as;

Model 1:

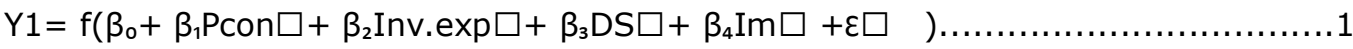


Table 1: OLS Estimation of domestic debt function from 1990 to 2015

\begin{tabular}{|l|l|l|l|}
\cline { 2 - 4 } \multicolumn{1}{c|}{} & \multicolumn{3}{l|}{ (Model 1) Y1 } \\
\hline Variable & Coef. & t-stat & Prob \\
\hline C & & 4.1895 & 0.0004 \\
DI & 353.844 & -5.5113 & 0.0000 \\
IMP & 4 & -4.2462 & 0.0004 \\
SAV & -4.4196 & -1.5653 & 0.1324 \\
DCU & -3.6437 & 6.9403 & 0.0000 \\
& -1.4482 & & \\
& 2.5429 & & \\
\hline Adj. R & 0.70 & \multicolumn{2}{|l}{} \\
\hline F-Stat & 15.33 \\
& & & \\
\hline DW & 1.7094 & \multicolumn{2}{|l}{} \\
\hline
\end{tabular}

The table one above shows the estimation results for model one (Y1). The analysis result indicates that all the signs of the coefficients are in line with the theoretical underpinning. The t-ratios are more than 2, while all the probabilities are less than 0.05 which tells of the significance of the variables. The adj. $\mathrm{R}^{2}$ is $70 \%$, showing that the model is good and hence captures the maximum variations of the model.

\section{Estimation of Model 2}

The estimation of model two being the External Debt model is expressed in the functional form below as;

\section{Model 2:}

$Y 2=f\left(\beta_{0}+\beta_{1}\right.$ Gcon $\square+\beta_{2}$ Inv.exp $\square+\beta_{3} N S \square+\beta_{4}$ Inf $\left.+\varepsilon \square\right)$ .2

Adopting E-Views method of estimation, we regress the above model. The result is provided in table 2 below.

Table 2: OLS Estimation of external debt function from 1990 to 2015

\begin{tabular}{|l|l|l|l|}
\cline { 2 - 4 } \multicolumn{1}{c|}{} & \multicolumn{2}{l|}{ (Model 2) Y2 } \\
\hline Variable & Coef. & t-stat & Prob \\
\hline C & 67.6293 & 0.4441 & 0.6638 \\
GC & 3.4187 & 1.1118 & 0.2808 \\
INV & -2.6908 & -1.9129 & 0.0734 \\
INF & 0.3789 & 0.9129 & 0.3734 \\
AR(1) & 1.1983 & 5.2744 & 0.0001 \\
AR (2) & -0.2709 & -1.2238 & 0.2368 \\
& & & \\
\hline Adj. R & & \\
\hline F-Stat. & 0.92 & 0.0000 & \multicolumn{2}{|l|}{} \\
Prob. & & \multicolumn{2}{|l}{} \\
\hline DW & 1.86 \\
\hline
\end{tabular}

The table above shows the analysis results of model 2. Here, all the signs of the coefficients are in line with the theoretical underpinning. The variables are significant at $5 \%$ level except for investment variable (inv). We see also that the t-ratios are significant. The adj. $\mathrm{R}^{2}$ is $92 \%$, signifying that the model is good and thus captures the maximum variations of the variables. The $F$ Statistic in turn shows a significant result with probability of $F$ Statistic being 0.0000 which is an indication that the overall model is statistically significant. 


\section{Estimation of Growth Model}

With our third model, we adopt two variables being the domestic and external debts. We normalize them by percentage GPD. This choice of normalizing is to help us avoid some econometric problems such as multicollinearity.

$G R O=f\left(\beta_{0}+\beta_{1} D D+\beta_{2} E D+\varepsilon \square\right)$. 3

Equation 3 is our Growth model. Estimation results are shown below in table 3 below

Table 3: OLS Estimation of growth function from 1990 to 2015)

\begin{tabular}{|c|c|c|c|}
\hline & (Model 2 & & \\
\hline $\begin{array}{l}\text { Variabl } \\
\text { e }\end{array}$ & Coef. & t-stat & Prob \\
\hline $\begin{array}{l}\text { C } \\
\text { LNEXD } \\
\text { LNDD }\end{array}$ & $\begin{array}{l}3.9089 \\
-0.3391 \\
-0.1253\end{array}$ & $\begin{array}{l}6.5962 \\
-37818 \\
-0.8895\end{array}$ & $\begin{array}{l}0.0000 \\
0.0010 \\
0.3839\end{array}$ \\
\hline Adj. $R^{2}$ & \multicolumn{3}{|l|}{0.42} \\
\hline $\begin{array}{l}\text { F-Stat. } \\
\text { Prob. }\end{array}$ & \multicolumn{3}{|l|}{0.0007} \\
\hline DW & \multicolumn{3}{|l|}{1.60} \\
\hline
\end{tabular}

The table above shows the result for the growth model, equation 3. It should be noted that the percentage GDP of domestic debt and external debt have a negative relationship with annual growth. This result further explains that domestic debt has no impact on economic growth. The probability of F-static shows a value of 0.0007 and DW value of 1.60 indicates that the variables are significant and shows that overall model is also significant.

Since both types of debt are inefficiently managed and hence have negative impact on growth of the economy. A more positive result could also be achieved if debt is efficiently managed and used in productive sectors only, and corruption put under control.

Since both types of debt are inefficiently managed and hence have negative impact on growth of the economy. A more positive result could also be achieved if debt is efficiently managed and used in productive sectors only, and corruption put under control.

Since both types of debt are inefficiently managed and hence have negative impact on growth of the economy. A more positive result could also be achieved if debt is efficiently managed and used in productive sectors only, and corruption put under control.

\section{CONCLUSION AND RECOMENDATIONS}

It is not surprising to see that in order to bridge the fiscal gap of revenue and expenditure, the government of Ghana resorts to excessive borrowings which eventually does more harm than good to the economy. The results presents could be due to a number of limitations. There is a possibility that the measurements of the three dependent variables might be misleading because data based on the external and internal government debt are usually dubious due to corruption. As opined by Armony et al. (2005), quite a number of economists and politicians and or financial experts explain that the financial crisis can be described by macroeconomic opposing factors mainly by the corruption of public officials that has had a detrimental propensity, has designed the wrong policy and institutional malfunction. A lower debt level has the propensity to have a positive effect on growth levels. However the adverse can be accounted for, in the case of high debt level record of above a 
particular threshold, an additional debt will only result in the birthing of a rather negative impact on economic growth (Pattillo et al. 2002).

As a policy implication, we recommend that government debt borrowing should be discouraged while increasing the revenue base through tax reform programs is encouraged. Again a healthy threshold should be maintained as an alternative to finance its projects. Among these recommendations, suitable economic environment should be provided to private sector investors.

In order to quench the acute curiosity of researchers, another interesting extension of the findings presented in this study would be to delve deeper into finding the specific conditions required to reverse the negative impact of Ghana's public debt and its economic growth.

Ghana requires a policy action that can contribute to rectifying these serious abnormalities in our development and nation building system. Ghana needs new business policies and regulations for development and a revision of our financial sector since the old pattern of just borrowing itself out of poverty and inadequacies no longer fits. These new policies are expected to be dynamic and responsive to the challenges facing Ghana as a developing country in order to get our priorities right.

One research opportunity will be to explore quantitatively the risk estimation of government debt management, the supervision and public information of debt which is usually accompanied by undesirable impact on economic growth.

\section{ACKNOWLEDGEMENTS}

The authors are grateful to His Excellency Amb. Kojo Amoo Gottfried, Prof. Zhang Xuegong and Ms. Kani Sangare for their support in the diverse ways in which they contributed to making this write up a success. Special thanks to the Editors of the Journal for the many valuable comments on the previous version of the paper which has improved its quality and content to the present state.

\section{REFERENCES}

- Adofu, I., and M. Abula."Domestic debt and the Nigerian economy." Current Research Journal of Economic Theory 2.1 (2010): 22-26.

- Ajayi, S. I. (1991). Macroeconomic Approach to External Debt-The case of Nigeria (No. RP_08).

- Barfour O. 1995, Ghana: The burden of debt service payment under structural adjustment. African Economic Research Consortium Paper No.33 (Nairobi Initiative Publishers 1995)

- Basu, K. (1993). On the Suddenness of International Debt Crises. Sankhyā: The Indian Journal of Statistics, Series B, 291-296.

- Bekaert G. C. (2005). "Market Integration and Contagion". Journal of Business by The University of Chicago, 78(1): 403-444, CrossRef

- Bordo, M. D., Meissner, C. M., \& Stuckler, D. (2010). Foreign currency debt, financial crises and economic growth: A long-run view. Journal of international Money and Finance, 29(4), 642-665, CrossRef

- Charles, O. (2012). "Domestic Debt and the Growth of Nigerian economy." Research journal of finance and accounting 3.5: 45-56.

- Darcy F., Samuel M., Mauricio N., Francisco R. (2008) Latin American Emerging Markets: The Mexican Crisis of 1994 Chapter three

- Eduardo T. (2008) International Crisis 2007-2009, Effects in Mexico, Chapter two

- Edwards S, \&Susmel R. (1999) "Contagion and Volatility in The1990's". Draft for Conference Presentation, Universidad El Cema.

- Edwards S. and Susmel R.(2000) "Interest rate Volatility in Emerging markets: Evidence from the 1990s" NBER Working Paper 
- ElioIannuzzi M.B. (2010),"Global financial crisis: causes and perspectives", EuroMed Journal of Business, Vol. 5 Iss 3 pp. 279 - 297.

- Ghana|Joy Business 2016, Fitch maintains Ghana's Credit Ratings at B with negative outlook

- Greene, J. (1989). The External Debt Problem of Sub-Saharan Africa. Staff Papers (International Monetary Fund), 36(4), 836-874, CrossRef

- International Monetary Fund Washington DC. Economic and Financial Review, Vol 42 No2, 41-66.

- James O. B., Symon K., Aquilars K. M., Mose G. (2015). Effect of domestic debt on economic growth in the east African community. American Journal of Research Communication, 3(9): 73-95

- Khan, Mohsin S., and Nadeem UI H. 1985, "Foreign Borrowing and Capital Flight: A Formal Analysis," Staff Papers, International Monetary Fund, Vol. 32 (December).

- Klender C., Jorge C., Martha R., Gabriela T. (2008). Financial Crisis of USA and the Theory of Transmission, Case of Mexico and Argentina Chapter four

- Kumar, M., \& Woo, J. (2010). Public debt and growth. IMF working papers, 1-47, CrossRef

- Lagunes M. \& Watkins, K. (2008). "Efecto De Las Crisis Anticipadas Y No AnticipadasSobre El ContagioFinancieroInternacional". Xii Congreso Internacional De Investigación En CienciasAdministrativas (Págs. 30). Tijuana: Acacia.

- Moki, M. (2012). An analysis of the relationship between public debt and economic growth in Africa (Doctoral dissertation).

- Nguyen, T. Q., Clements, M. B. J., \& Bhattacharya, M. R. (2003). External debt, public investment, and growth in low-income countries (No. 3-249). International Monetary Fund, CrossRef

- Omotoye, R. O., Sharma, H. P., Ngassam, C., \& Eseonu, M. (2006). Sub-Saharan Africa's debt crisis: analysis and forecast based on Nigeria. Managerial Finance, 32(7), 606-620, CrossRef

- Pattillo C., Ricci L. and Poirson H. (2001): Non-linear Impact of External Debt on Growth IMF Working Paper International Monetary Fund Washington DC.

- Pattillo, C. A., Poirson, H., \& Ricci, L. A. (2002). External debt and growth (No. 2002-2069). International Monetary Fund.

- Prorokowski, L. (2013). Lessons from financial crisis contagion simulation in Europe. Studies in Economics and Finance, 30(2), 159-188, CrossRef

- Reinhart, C. M., \& Rogoff, K. S. (2011). From financial crash to debt crisis. The American Economic Review, 101(5), 1676-1706, CrossRef

- Rodríguez, M., Torres, G., Castillo, J., \& Cortez, K. ANALYSIS OF FINANCIAL CRISIS MODELS: CAN SCIENCE EXPLAIN FINANCIAL CRISES WITH THE EXISTENT MODELS?. Financial crisis, 2.

- Saint-Paul, G. (1992). Fiscal policy in an endogenous growth model. The Quarterly Journal of Economics, 107 (4), 1243-59, CrossRef

- Schclarek, A. (2004). Debt and economic growth in developing and industrial countries. Lund University Department of Economics Working Paper, 2005, 34.

- Stephen N. 2014, Ghana's debt distress threatens economic livelihoods of itscitizens.http://www.ghanaweb.com/GhanaHomePage/features/columnist. 